\title{
ARTICLE \\ Effect of Dates and Methods of Sowing with and without Hydroprim- ing on Growth, Phenology and Yield of Sorghum under Semi Arid Conditions of Eritrea
}

\author{
Berhane Teklesenbet Negassi ${ }^{*}$ Woldeamlak Araia Nitya Nand Angiras* \\ Department of Agronomy, Hamelmalo Agricultural College, Keren, Eritrea
}

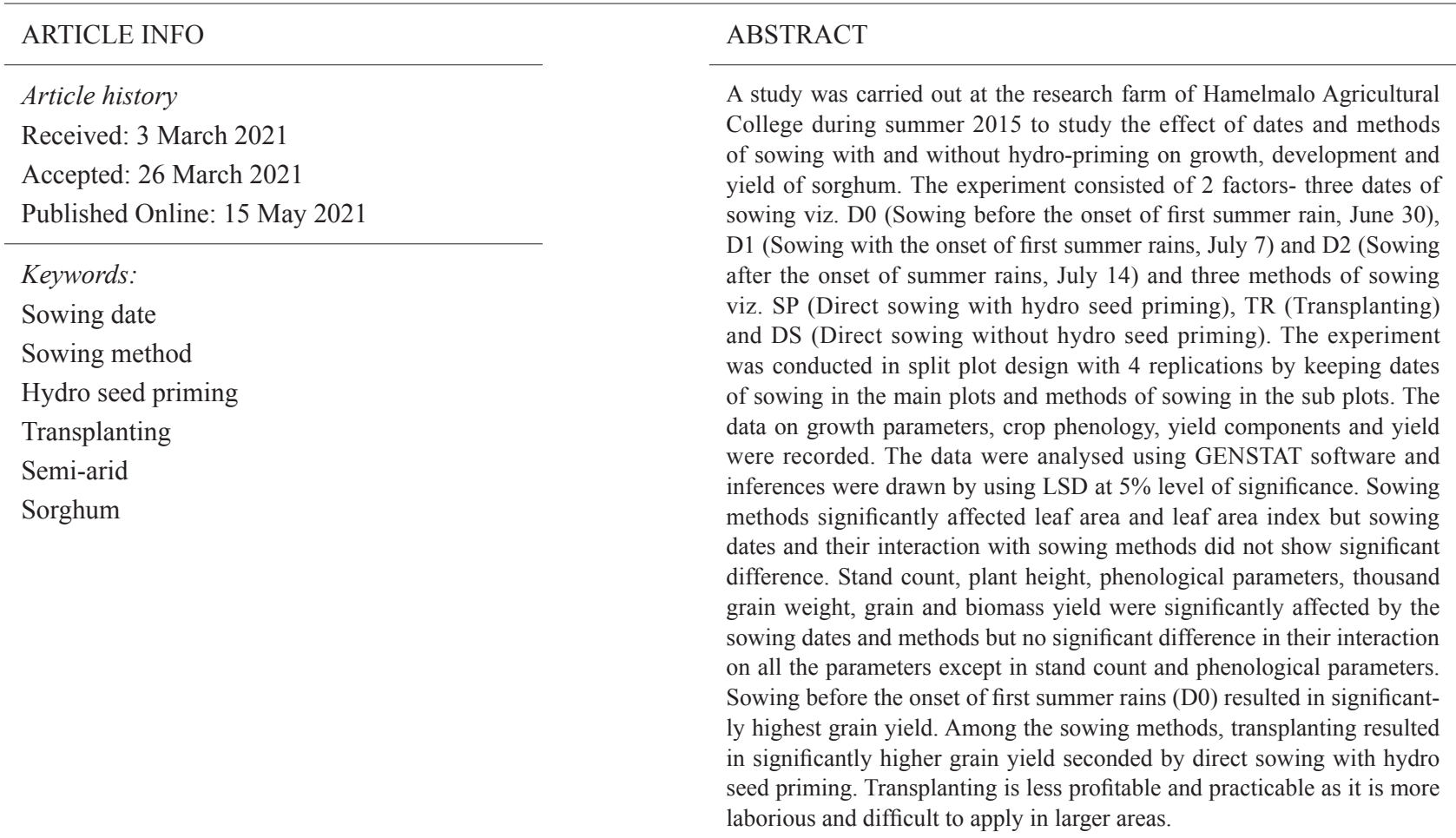

\section{Introduction}

Sorghum (Sorghum bicolor L.) belonging to the family Poaceae is an indigenous crop of Africa and is the most important staple food of many rural communities in the drier regions of Africa and Asia. It is a major source of calories and proteins for millions of people. In Eritrea, it is the main crop for human consumption which is cul-

\footnotetext{
*Corresponding Author:

Berhane Teklesenbet Negassi,

Department of Agronomy, Hamelmalo Agricultural College, Keren, Eritrea,

Email: berhaneteklesenbet2@gmail.com

Nitya Nand Angiras,

Department of Agronomy, Hamelmalo Agricultural College, Keren, Eritrea;

Email: angirasnsk@gmail.com
} 
tivated in six administrative zones: Gash Barka, Anseba, Debub, Maekel, Northern Red Sea (NRS) and Southern Red Sea (SRS) with a total area of cultivation, production and productivity 224,559 ha, 121,714 tonnes and $0.54 \mathrm{t} / \mathrm{ha}$, respectively in average of three years (20132015) ${ }^{[1]}$. It is used to make human foods like porridge, pop-roasting, traditional flat bread (Qicha \& Injera) and traditional drink (Siwa) and a source of raw material for beer industry. It is also used as feed for animals, fuel for cooking, construction material for huts and mats.

The total area for field crops in this sub zone during the year 2013 and 2014 was 9100 ha and 9243 ha, respectively. Out of these a total of 2850 ha in 2013 and 2764 ha in 2014 was occupied by sorghum with an average yield of 1.7 and $4.57 \mathrm{q} / \mathrm{ha}$, respectively ${ }^{[2]}$.

The productivity of sorghum in semi-arid regions of Eritrea is lower than the world. This is attributed to poor crop establishment, low and erratic distribution of rainfall and poor crop management. Among these, crop establishment is often poor in the semi-arid tropics of Eritrea. Adequate crop stand establishment is essential for efficient use of water and light, which is a pre-requisite for success of crop production. Poor seedling establishment or crop stand results in lower yield. In such cases the surface layer of soil dries quickly and temperature rises rapidly. The formation of surface crust and hard layers in the soil surface could form impermeable barriers to shoot emergence and root penetration, respectively. In addition the plant eventually emerges often slowly and becomes highly susceptible to abiotic and biotic stresses ${ }^{[3]}$.

The major reasons for low yield are drought stress, inadequate supply of agricultural inputs, poor soil fertility, lack of improved varieties, high infestation of insect pests and diseases, severe weed infestation including parasitic weed like Striga and poor crop management practices. Even though sorghum and pearl millet are drought tolerant crops under semi-arid conditions, the production is most of the time challenged by erratic rainfall pattern often characterized by total failure or delay in the on-set and early cessation of the rain fall during the main rainy season (June-September). It is critical to provide farmers with various techniques to enable them to minimize the risk of losing their harvests so that food security could be achieved ${ }^{[4]}$.

The crop management techniques that help for better crop establishment, higher yield and resistance to biotic and abiotic stress in arid regions of the tropics for sorghum production are seed priming and transplanting which have proved to be better techniques compared to direct sowing without priming ${ }^{[5]}$.

Hydro seed priming was found to improve crop es- tablishment, reduce disease infestation and improve the productivity of the crop compared to non-primed seeds. Studies carried out on hydro seed priming has proved that the seed could germinate early, root and shoot development could start rapidly and grow more vigorously compared to non-primed seeds. Date of sowing is another constraint affecting the production of sorghum. There are farmers in Hamelmalo area who plant their crops before the onset of summer rains whereas others delay the sowing until they receive rainfall 2-3 times which affects the yield of sorghum.

Since it is difficult to decide on the date of sowing based on calendar dates due to erratic rainfall situation and distribution in semi-arid and arid areas, it is better to plant crops based on the number of rains particularly before the start of the rainy season so that the crop could utilise the first flush of rainfall for crop growth and development. According to ${ }^{[6]}$ the preferable sowing time for sorghum varies from the end of June to 2 nd week of July, depending on the location, climate and variety. Sowing sorghum during the end of June before the start of rains is preferable because it helps the crop to utilise the first flash of nitrogen and first drop of rainfall for its growth and development. Nitrogen is volatile and leaching takes place in continuous rainfall situation hence the crop will not be able to utilise the available nitrogen if the sowing date is delayed. Therefore keeping in view the above facts in mind the present investigation was carried out to find the effect of Dates and Methods of sowing on growth and yield of sorghum under semiarid conditions of Hamelmalo in Eritrea.

\section{Materials and Methods}

A field experiment was conducted during summer season of 2015 at the experimental farm of Hamelmalo Agricultural College located at latitude of $15^{\circ}$ $52^{\prime} 18^{\prime \prime} \mathrm{N}$; longitude of $38^{\circ} 27^{\prime} 55^{\prime \prime} \mathrm{E}$ and altitude of $1280 \mathrm{~m}$ above mean Sea level in semi-arid conditions. The experiment was conducted in split plot design by assigning three dates of sowings viz before onset of first summer rains (June 30, D0), with the onset of the first summer rains (July 7, D1) and after the onset of the summer rains (July 14, D2) in main plots and three methods of sowing viz direct sowing without hydro-seed priming (DS), direct sowing with hydro-seed priming (SP), and Transplanting(TR) in subplots, each replicated four times. Most farmers of the area plant sorghum with the onset of summer rains (D1) which was kept as a check (control).

Hamelmalo variety of sorghum was sown in the experiment at a row spacing of $75 \mathrm{~cm}$ and plant spacing of 
$20 \mathrm{~cm}$ in a gross plot area of $4.5 \mathrm{~m} \times 3.0 \mathrm{~m}$ and net plot area of $3 \mathrm{~m} \times 2 \mathrm{~m}$.

Soil of the experimental field was sandy loam which comprises $59.8 \%$ sand, $26.6 \%$ silt and $13.6 \%$ clay with $\mathrm{pH}$ of 8.28 .

The area receives an average annual rain fall of $436.34 \mathrm{~mm}$. During the year of experiment 2015 the area received $264.5 \mathrm{~mm}$ of rainfall which was poorly distributed and not sufficient. The crop received 1.2\%, 38.4\%, $53.3 \%$ and $7 . \%$ of rainfall in June, July, August and September, respectively.

In direct sowing with hydro seed priming, the seed was soaked in water for 10 hours and dried in shade in the morning hours and then planted immediately into the field. In transplanting the seeds were planted in a nursery bed $(2 \mathrm{~m} \times 1.5 \mathrm{~m})$ in three different dates $(17,24$ June \& 01 July) that matched with the treatments and emerged in four days after sawing. Transplanting was carried out into the main field after the seedlings were grown for 10 days (seedlings with 2-3 leaves). However, in direct sowing without hydro seed priming, the seed was planted directly to the field without soaking it in water as practiced by farmers.

The data were analysed using GENSTAT software for the Analysis of Variance and LSD at 5\% was estimated for mean comparison. The correlation analysis was worked out to see the relationship of the agronomic parameters with grain yield, biomass yield and harvest index.

A fertilizer dose of $41 \mathrm{~kg} \mathrm{~N}$ and $46 \mathrm{~kg} \mathrm{P}_{2} \mathrm{O}_{5}$ per hectare was applied through di-ammonium phosphate. The fertilizer $\mathrm{P}$ was applied at sowing while $\mathrm{N}$ was applied in split with $1 / 3$ dose at sowing and $2 / 3$ at 35DAS. The fertilizer was applied in rows and incorporated to the soil.

The field was hand weeded twice with hand hoe.

\subsection{Data Collected}

\subsubsection{Growth Parameters}

The data on growth parameters like stand count, plant height, leaf area and leaf area index were recorded at their maximum values. Leaf area (LA) in $\mathrm{m}^{2}$ was estimated by $\mathrm{L}$ X W x CF where $\mathrm{L}=$ length of the leaf, $\mathrm{W}=$ maximum width of the leaf and $\mathrm{CF}=$ correction factor which is estimated to be 0.75 for sorghum. It was measured on per plant basis manually by measuring the length and width of the leaves. Leaf area index was obtained by dividing the total leaf area of one plant by the land area covered under it.

\subsubsection{Development Parameters}

The data on crop development like date of heading/flowering and maturity were recorded. Heading date was recorded when $50 \%$ of the plants produced heads and the number of days taken from sowing up to heading were counted. Maturity date was recorded when $90 \%$ of the plants reached maturity stage and the number of days taken from sowing up to maturity was counted.

\subsubsection{Yield and Yield Component}

Yield components such as panicle length, panicle weight and thousand grain weight were recorded. The biomass yield, stover yield, grain yield and harvest index were recorded after harvesting and drying of the plot wise produce. Harvest index is expressed in per cent and calculated as $\mathrm{HI}=\mathrm{GY} / \mathrm{BY} \times 100$ where $\mathrm{HI}=$ harvest index, $\mathrm{BY}=$ biomass yield, $\mathrm{GY}=$ grain yield .

\section{Results and Discussion}

\subsection{Effect on Growth}

\subsubsection{Effect on Stand Count (No./ $\left.\mathbf{m}^{2}\right)$}

There was a significant difference among the different sowing dates, sowing methods and their interaction on stand count of sorghum (Table 1). Sowing after the onset of summer rains resulted in the highest stand count followed by sowing before the onset of summer rains). Transplanting followed by direct sowing with hydro seed priming produced significantly higher stand count.

Direct sowing with hydro seed priming before the onset of summer rains gave the highest stand count followed by direct sowing with the onset of first summer rains. The lowest stand count was obtained with direct sowing without hydro seed priming after the onset of the first summer rains. This can be attributed to saturation of soil with water during 'sowing with the onset of summer rains' which enabled the seeds to get imbibed very fast and germinated sooner than sowing before the onset of summer rains. In sowing before the onset of summer rains (June 30) and Sowing after the onset of summer rains (July 14) the stand count was lower because of erratic and non-consistency nature of the rainfall which reduced the emergence of the crop.

Transplanting showed better stand count followed by direct sowing with hydro seed priming that emerged and established earlier than direct un-primed sown seeds which could be due to the effect of soaking that accelerated enzymatic activity in the seed. While comparing 
direct sowing with hydro seed priming and direct unprimed sowing, the plant population in direct sowing with hydro seed priming showed $10.5 \%$ increase compared to direct un-primed sowing.

Table 1. Effect of dates of sowing, methods of sowing and their interaction on growth parameters and phenology of sorghum

\begin{tabular}{|c|c|c|c|c|c|c|}
\hline Treatment & SC & LA & LAI & PH & HD & MD \\
\hline \multicolumn{7}{|c|}{ Dates of sowing } \\
\hline D0 & 105.2 & 0.105 & 0.949 & 141.8 & 64 & 85 \\
\hline D1 & 109.1 & 0.109 & 0.980 & 137.9 & 66 & 86 \\
\hline D2 & 91.1 & 0.103 & 0.928 & 126 & 72 & 89 \\
\hline $\operatorname{LSD}(5 \%)$ & 12.12 & NS & $\mathrm{NS}$ & 5.53 & 1.373 & 1.489 \\
\hline CV (\%) & 6.9 & 10.2 & 10.2 & 2.3 & 1.2 & 1 \\
\hline \multicolumn{7}{|c|}{\begin{tabular}{|l|} 
Methods of sowing \\
\end{tabular}} \\
\hline SP & 104.4 & 0.113 & 1.013 & 132.6 & 69 & 87 \\
\hline TR & 106.4 & 0.098 & 0.885 & 145.9 & 61 & 82 \\
\hline DS & 94.5 & 0.107 & 0.958 & 127.2 & 71 & 91 \\
\hline LSD (5\%) & 6.5 & 0.005 & 0.0488 & 10.84 & 1.098 & 0.705 \\
\hline CV (\%) & 6.9 & 10.2 & 10.2 & 2.3 & 1.2 & 1 \\
\hline \multicolumn{7}{|c|}{ Dates of sowing $\mathbf{x}$ Methods of sowing } \\
\hline D0SP & 111.5 & 0.113 & 1.021 & 143 & 64 & 85 \\
\hline D0TR & 106.7 & 0.097 & 0.875 & 143.4 & 60 & 82 \\
\hline D0DS & 97.2 & 0.106 & 0.950 & 139.1 & 68 & 87 \\
\hline D1SP & 109.7 & 0.117 & 1.056 & 134.7 & 67 & 87 \\
\hline D1TR & 109 & 0.099 & 0.891 & 152.5 & 62 & 80 \\
\hline D1DS & 108.5 & 0.110 & 0.992 & 126.4 & 69 & 91 \\
\hline D2SP & 92 & 0.107 & 0.964 & 120.1 & 76 & 90 \\
\hline D2TR & 103.5 & 0.099 & 0.888 & 141.9 & 61 & 85 \\
\hline D2DS & 77.7 & 0.104 & 0.932 & 116.1 & 77 & 92 \\
\hline LSD (5\%) & 14.03 & NS & NS & NS & 1.922 & 1.657 \\
\hline CV (\%) & 7.4 & 6 & 6 & 9.3 & 1.9 & 1 \\
\hline $\begin{array}{l}\text { Grand } \\
\text { Mean }\end{array}$ & 101.8 & 0.106 & 0.9521 & 135.2 & 67 & 87 \\
\hline
\end{tabular}

Note: D0- sowing before onset of summer rains; D1- Sowing with the onset of first summer rains; D2- Sowing after the onset of first summer rains; $\mathrm{SP}=$ direct sowing with Hydro seed priming; $\mathrm{TR}=$ Transplanting $\mathrm{DS}=$ Direct sowing without Hydro seed priming; $\mathrm{SC}=$ stand count; $\mathrm{LA}=-$ leaf area; $\mathrm{LAI}=$ leaf area index; $\mathrm{PH}=$ plant height; $\mathrm{HD}=$ heading date; $\mathrm{MD}=$ maturity date

The similar results were reported by ${ }^{[7,8]}$ who also found that hydro seed priming gave the highest plant population.

\subsubsection{Effect on Leaf Area $\left(\mathrm{m}^{2} /\right.$ plant $)$}

The data presented in Table 1 indicate that while leaf area was not significantly affected by sowing dates, method of sowing influenced the leaf area significantly.

The trend in leaf area at various days after sowing showed that the highest leaf area was at 60 DAS and then declined. Sowing with the onset of first summer rains (July 7) showed numerically highest leaf area at 60 DAS. Sowing after the onset of the first summer rains (July 14) which is a delayed sowing date showed higher leaf area until 60 DAS but after 80 DAS there was a reduction in leaf area which showed the lowest leaf area compared to the other sowing dates. These results are in agreement with the findings of ${ }^{[9,10]}$ who reported that delayed sowing in sorghum cultivars showed a reduction in leaf number and leaf area. These findings are also in agreement with those of ${ }^{[13]}$ who found out the highest leaf area in early July sowing.

Transplanting resulted in significantly highest leaf area at 60DAS. Direct sowing with hydro seed priming and direct sowing without hydro-seed priming showed the same trend even though direct sowing with hydro seed priming was slightly better than direct sowing without hydro seed priming during the growing period.

Transplanting with the onset of summer rains was better in leaf area until 60 DAS there after it declined tremendously. Direct sowing without hydro seed priming before the onset of first summer rains produced the lowest leaf area.

\subsubsection{Effect on Leaf Area Index (LAI)}

While the dates of sowing did not influence the LAI significantly, methods of sowing caused a significant difference in leaf area index (Table 1).

Sowing with the onset of the summer rains resulted in numerically highest leaf area index at 60 DAS.

Direct sowing with hydro seed priming showed significantly highest Leaf Area Index followed by direct seeding without priming.

Direct sowing with hydro priming after the onset of the first summer rains had numerically the highest Leaf Area Index followed by direct sowing with hydro seed priming before onset of summer rains.

\subsubsection{Effect on Plant Height (cm)}

\section{Dates of Sowing}

The final plant height was significantly influenced by sowing dates and methods of sowing (Table1). However, their interaction did not influence the plant height significantly.

Sowing before the onset of the summer rains and sowing with the onset of the summer rains. being statistically at par resulted in significantly higher plant height. It may be attributed to efficient utilization of both the first flash of rainfall and nitrogen than the late planted crops resulting in better growth ${ }^{[11]}$.

Transplanting produced significantly tallest plants followed by direct sowing with hydro seed priming. It is because the transplanted seedlings were grown in nursery 10 days before the direct sowing with hydro seed priming and direct sowing without priming. Transplanting showed an increase in plant height than direct sowing with hydro 
seed priming and direct sowing without priming by $10 \%$ and $14 \%$, respectively. The taller plant height observed in direct sowing with hydro seed priming could be due to early emergence, vigorous seedling establishment, tolerance to rainfall fluctuations, drought and efficient utilization of rain fall received during the growing season.

Dates of sowing and sowing methods interaction have not influenced plant height significantly. Transplanting with the onset of the summer rains produced numerically tallest plants followed by direct sowing with hydro seed priming before the onset of the summer rains (Table 1). Direct sowing with hydro seed priming gave taller plants than direct sowing without priming The above results are contrary to the finding of ${ }^{[12]}$ who reported shorter plant height in transplanted crops due to transplanting shock in longer aged seedlings.

However, the results from direct sowing with hydro seed priming were in line with that of ${ }^{[13,14]}$ who reported that plant height was better in hydro seed priming compared to direct sowing without priming.

\subsection{Effect on Phenology}

\subsubsection{Days taken for Heading}

Dates of sowing, methods of sowing and their interaction significantly influenced the days taken for heading (Table 1).

Sowing before the onset of the summer rains took significantly the lowest number of days to heading followed by Sowing with the onset of the summer rains. Sowing after the onset of the summer rains took significantly highest number of days to heading. Similar results were reported by ${ }^{[15]}$ who also found a lesser number of days to heading by sowing the crop in dry soil conditions which is before onset of rains.

Transplanting took significantly lowest number of days to heading followed by direct sowing with hydro seed priming. Direct sowing without priming took significantly highest number of days to heading. The direct un-primed sown plants produced heading late due to lack of soil moisture towards the end of the growing season. These results are in agreement with those of ${ }^{[16]}$ who also revealed that direct hydro seed priming produced heads earlier than direct un-primed sowings.

The data on interaction effect of sowing dates and method of sowing in Table1 reveal that irrespective of date of sowing, transplanting method took lesser number of days for heading as compared to direct methods of sowing with and without priming due to plantation of 10 days old seedlings. Irrespective of date of sowing, seed priming resulted in significantly early emergence of the heads due to its effect on faster initial growth of the seedlings compared to non seed priming. Irrespective of seed priming treatments, direct sowing before the onset of the summer rains resulted in significantly early heading than sowing after the onset of summer rains due to faster germination and growth of seedlings by utilization of first rain.

\subsubsection{Days taken for Maturity}

Dates of sowing, methods of sowing and their interaction significantly influenced the days taken for maturity (Table 1).

Sowing before the onset of the summer rains and sowing with the onset of the summer rains being statistically at par took a significantly lower number of days to maturity as compared to sowing after the onset of the summer rains. It can be attributed to faster rate of growth and development of the crop due to the first flash of rainfall and nitrogen in case of sowing before onset of rains and optimum moisture and temperature for growth in sowing with the onset of summer rains.

Transplanting was the earliest in maturity due to reduced length of growing season by raising seedlings in nursery compared to direct sowing with hydro seed priming. Direct sowing with un-primed seeds took the highest number of days to maturity. These results are in direct conformity with those of ${ }^{[17]}$ who also reported that transplanted crops matured earlier than direct sown crop.

Data on interaction effect of sowing dates and methods presented in Table 1 revealed that irrespective of sowing dates transplanting method resulted in significantly earlier maturity over the direct sowing. While transplanting with the onset of the summer rains resulted in significantly earliest maturity, direct sowing without priming caused significantly latest maturity of the crop.

\subsection{Effect on Yield Components}

Panicle length, panicle weight and thousand grain weight were significantly influenced by dates of sowing and methods of sowing (Table 2). However, panicle weight was not affected significantly by the date of sowing.

Sowing before the onset of rains and with the onset of rains being at par produced significantly longer panicles and thousand grain weight compared to sowing after the onset of rains because of favourable moisture and temperature conditions for proper growth and development of the crop. Sowing before onset of rains produced numerically highest weight of panicles followed by sowing with the onset of summer rains.

Among the methods of sowing, transplanting resulted 
in significantly longer panicles, highest panicle weight and thousand grain weight over other methods of sowing due to benefit of ten days initial growth of seedlings in the nursery facilitating early flowering and maturity which enhanced the seed size. However, direct sowing with hydro seed priming was statistically at par with transplanting in influencing the panicle length and next best in panicle weight and thousand grain weight because it enabled imbibitions of water to initiate and facilitate earlier germination and better crop establishment, growth and development of the crop. These findings are in agreement with those of ${ }^{[18]}$ who also reported that seed priming increased the thousand grain weight as compared to non primed seeds.

Interaction of dates and methods of sowing did not significantly influence all the yield attributes of the crop. However, transplanting with the onset of summer rains resulted in numerically highest values of all the yield attributes.

\subsection{Effect on Yields}

Biological yield, grain yield and stover yields were significantly influenced by dates and methods of sowing. But the harvest index was not influenced significantly by them. Interaction of dates and methods of sowing did not influence significantly all the yields and harvest index (Table 2).

Table 2. Effect of dates of sowing, methods of Sowing and their interaction on yield \& yield components of sorghum.

\begin{tabular}{|c|c|c|c|c|c|c|c|}
\hline Treatment & GY & BY & SW & HI (\%) & PL & PW & TGW \\
\hline \multicolumn{8}{|c|}{ Dates of sowing } \\
\hline D0 & 2569 & 8710 & 6140 & 28.86 & 22.65 & 74.6 & 22.30 \\
\hline D1 & 1875 & 7778 & 5903 & 23.94 & 22.47 & 71.3 & 21.92 \\
\hline D2 & 1339 & 5196 & 3857 & 24.77 & 19.43 & 58.4 & 20.00 \\
\hline LSD (5\%) & 460 & 468.4 & 186.3 & NS & 2.08 & NS & 1.47 \\
\hline CV (\%) & 13.8 & 3.7 & 2 & 12.4 & 5.60 & 11.2 & 4 \\
\hline \multicolumn{8}{|c|}{ Methods of sowing } \\
\hline SP & 1914 & 7022 & 5108 & 26.28 & 21.47 & 67.5 & 20.58 \\
\hline TR & 2277 & 8192 & 5915 & 27.28 & 22.54 & 79.9 & 24.25 \\
\hline DS & 1593 & 6469 & 4876 & 24.01 & 20.53 & 56.9 & 19.42 \\
\hline LSD (5\%) & 408.6 & 700.9 & 378.4 & NS & 1.427 & 6.49 & 1.415 \\
\hline CV $(\%)$ & 13.8 & 3.7 & 2 & 12.4 & 5.60 & 11.2 & 4 \\
\hline \multicolumn{8}{|c|}{ Dates of sowing $x$ Methods of sowing } \\
\hline D0SP & 2833 & 9000 & 6167 & 31.43 & 23.3 & 77.5 & 22.25 \\
\hline D0TR & 2667 & 9125 & 6458 & 27.61 & 22.47 & 80 & 24.00 \\
\hline D0DS & 2208 & 8004 & 5796 & 27.53 & 22.17 & 66.3 & 20.75 \\
\hline D1SP & 1842 & 7550 & 5708 & 24.36 & 22.85 & 70 & 21.00 \\
\hline D1TR & 2204 & 8788 & 6583 & 24.9 & 23.02 & 84.5 & 25.25 \\
\hline D1DS & 1579 & 6996 & 5417 & 22.57 & 21.52 & 59.5 & 19.50 \\
\hline D2SP & 1067 & 4517 & 3450 & 23.06 & 18.27 & 55 & 18.50 \\
\hline D2TR & 1958 & 6663 & 4704 & 29.32 & 22.12 & 75.2 & 23.50 \\
\hline D2DS & 992 & 4408 & 3417 & 21.92 & 17.9 & 45 & 18.00 \\
\hline LSD (5\%) & NS & NS & NS & NS & NS & NS & NS \\
\hline CV (\%) & 24.7 & 11.3 & 8.3 & 16.4 & 7.7 & 11.1 & 7.7 \\
\hline Grand mean & 1928 & 7228 & 5300 & 25.86 & 21.52 & 68.1 & 21.42 \\
\hline
\end{tabular}

Note: D0- sowing before onset of summer rains; D1- Sowing with the onset of first summer rains; D2-Sowing after the onset of the first summer rains; $\mathrm{SP}=$ direct seeding with Hydropriming; $\mathrm{TR}=$ Transplanting DS=Direct seeding without Hydropriming; GY=grain yield; $B Y=$ biomass yield; $\mathrm{SW}=$ stover weight; $\mathrm{HI}=$ harvestindex; $\mathrm{PL}=$ panicle length; Panicle weight; TGW=thousand grain weight

\subsubsection{Effect on Grain yield (kg/ha)}

Critical perusals of the data in Table 2 reveal that among the dates of sowing, sowing before the onset of summer rains resulted in significantly highest biomass yield $(8710 \mathrm{~kg} / \mathrm{ha})$, grain yield $(2570 \mathrm{~kg} / \mathrm{ha})$ and stover yield $(6140 \mathrm{~kg} / \mathrm{ha})$ and numerically highest harvest index $(28.86 \%)$ because of efficient utilization of first rain and the first flash of nitrogen in faster growth, development (Table1) and higher yield attributes (Table 2). Sowing with the onset of summer rains was the next best in producing higher yields. Sowing after the onset of rains produced the lowest yields because of the poorest growth, delayed development and production of lowest yield components. Similar findings were reported by ${ }^{[19,20]}$ who reported $30 \%$ yield increment due to first drop of rainfall and flash of nitrogen utilized by the crop in sowing before the onset of the summer rains.

It can be noted that the dates of sowing with better biomass yield were also the better in grain yield (Table 2). Late sowing produced less biomass due to insufficient amount of rain fall at later stage there by reducing both the biomass and grain yield compared to the other sowing dates. The above results are in line with the findings of ${ }^{[21}$ ${ }^{\text {and } 22]}$ who reported higher biomass yield in sowing before the onset of the summer rains over sowing with the onset of the first summer rains.

Among the methods of sowing, transplanting method resulted in significantly highest biomass yield $(8192 \mathrm{~kg} /$ ha), grain yield $(8192 \mathrm{~kg} / \mathrm{ha})$, stover yield $(6140 \mathrm{~kg} / \mathrm{ha})$ and numerically highest harvest index $(27.28 \%)$ due to advantage of transplanting of 10 days old seedlings of sorghum which helped in better stand, faster growth and development of the crop resulting in higher yield components (Table 1 and 2). Both the direct methods of sowing being statistically at par were next best in influencing biomass yield, grain yield and straw weight. However, direct sowing with hydro priming of the seeds was superior to direct seeding without hydro priming in increasing all types of yields. Transplanting showed a grain yield increase of $18.9 \%$ and $42.9 \%$ compared to direct sowing with hydro seed priming and direct sowing without priming, respectively. Direct sowing with hydro seed priming gave a yield increase of $20.15 \%$ compared to direct sowing without hydro seed priming which gave the lowest yield. 
The results in this experiment are similar to the finding of ${ }^{[23]}$ who reported a yield increase of about $59 \%$ in transplanting. ${ }^{[24]}$ mentioned that the yield from direct sowing with hydro seed priming were higher with a range of $10.2 \%$ to $31 \%$ compared to direct sowing without hydro seed priming. The yield increment in transplanting and direct sowing with hydro seed priming were due to improved crop establishment, vigour of seedlings, early flowering and maturing before early withdrawal of rainfall resulting in higher panicle weights.

It was noted that direct sowing with hydro seed priming had lower smut infestation as the fungal spores are removed with water during soaking as compared to the other methods of sowing. These findings are in agreement with those of ${ }^{[25]}$ who concluded that in direct sowing with hydro seed priming plants were more tolerant to diseases compared to non-primed ones.

The Coefficient of variation was higher for grain yield due to factors that were beyond control such as disease infestation, early withdrawal of rainfall and variation in management practices that resulted in bringing variation in the experiment. Despite that numerically, direct sowing with hydro seed priming before the onset of the summer rains was the best in grain yield $(2833 \mathrm{~kg} / \mathrm{ha})$ followed by transplanting $(2667 \mathrm{~kg} / \mathrm{ha})$ before the onset of the summer rains.

Interaction of dates of sowing and methods of sowing did not significantly influence the biomass yield, grain yield, stover weight and harvest index (Table 2). Cursory glance of the data reveals that transplanting and direct sowing with hydro seed priming before the onset of summer rains gave numerically higher biomass yield and grain yield due to higher plant population, taller plants, longer and heavier panicles. However, numerically higher stover yield was obtained with transplanting before onset or with the onset of summer rains. Direct sowing without seed priming after the onset of summer rains produced lowest biomass yield, grain yield and stover yield due to significantly lowest stand count and plant height and higher number of days taken for flowering and maturity (Table $1)$, which resulted in numerically lowest panicle length, panicle weight and thousand grain weight (Table 2).

\section{Correlation Studies}

The results of correlation studies made to find the relationship of biomass yield, grain yield and harvest index with the different growth, development and yield parameters have been presented in Table 3. The results of the study indicated that there was a negative and significant correlation between biomass yield vs heading and maturity date. The higher the biomass yield, lower the days taken to heading and maturity. The treatments with higher biomass took less number of days to heading and maturity.

The relationship between biomass and the other parameters was also positive and significant. This means that an increase in the values of stand count, plant height, panicle length and thousand grain weight resulted in higher biomass. The relationship of biomass yield with leaf area and leaf area index was positive but not significant.

Table 3. Correlation analysis on relationship between agronomic parameters and yield

\begin{tabular}{cccc} 
Parameter & Biomass yield & Grain yield & HI \\
Stand count & $0.549(* *)$ & $0.359(*)$ & $0.04(\mathrm{NS})$ \\
Leaf Area & $0.092(\mathrm{NS})$ & $0.181(\mathrm{NS})$ & $0.22(\mathrm{NS})$ \\
Leaf Area Index & $0.092(\mathrm{NS})$ & $0.181(\mathrm{NS})$ & $0.22(\mathrm{NS})$ \\
Plant Height & $0.805(* *)$ & $0.803(* *)$ & $0.63(* *)$ \\
Days to heading & $-0.784(* *)$ & $-0.686(* *)$ & $-0.41(*)$ \\
Days to Maturity & $-0.721(* *)$ & $-0.624(* *)$ & $-0.33(*)$ \\
Panicle Length & $0.854(* *)$ & $0.775(* *)$ & $0.49(*)$ \\
Panicle weight & $0.746(* *)$ & $0.686(* *)$ & $0.42(*)$ \\
Stover weight & $0.965(* *)$ & $0.77(* *)$ & $0.35(*)$ \\
Thousand Grain weight & $0.790(* *)$ & $0.766(* *)$ & $0.56(* *)$ \\
Biomass yield & --- & $0.911(* *)$ & $0.57(* *)$ \\
Grain yield & --- & --- & $0.838(* *)$ \\
\hline
\end{tabular}

Note: $(* *)$ - Highly significant at $1 \%$ level; $(*)$ - significant at $5 \%$ level; NS- Non significant.

These results were similar with findings of ${ }^{[26]}$ who mentioned on the positive correlation between grain yield and biomass in sorghum. Furthermore, biomass yield was positively and significantly correlated with grain yield and harvest index.

There was a negative correlation between grain yield vs heading and maturity date. The higher the grain yield the lower would be the number of days taken to heading and maturity. The treatments with higher grain yield took less number of days to heading and mature earlier.

There was significant and positive relationship between grain yield and stand count, plant height, panicle length, panicle weight and thousand grain weight which contributed to higher grain yield. The highest positive and significant correlation was observed in thousand seed weight and straw weight $\left(\mathrm{r}=0.76^{* *}\right.$ and $\left.\mathrm{r}=0.77^{* *}\right)$ whereas the lowest significant correlation was obtained from stand count $\left(\mathrm{r}=0.359^{*}\right)$. This finding is in agreement with that of ${ }^{[27,28]}$ who indicated that there was positive and highly significant correlation between grain yield and thousand seed weight. The relationship of grain yield with leaf area and leaf area index was positive but not significant. Grain 
yield was positively and significantly correlated with biomass yield and harvest index.

There was a negative and significant correlation between harvest index vs heading and maturity date. The higher the harvest index the lower is the number of days taken to heading and maturity. The treatments with higher harvest index took less number of days to heading and mature earlier.

The relationship between HI and other parameters was also positive and significant. This means that an increase in the values of plant height, panicle length, panicle weight, straw weight, grain yield, biomass yield and thousand grain weight resulted in higher harvest index. The above results are similar with findings of ${ }^{[29]}$ who mentioned a significant positive correlation between grain yield and harvest index. The relationship of harvest index with, stand count, leaf area and leaf area index was positive but not significant.

\section{Conclusions}

Among sowing dates, sowing with the onset of the first summer rains (July 7) was significantly superior in increasing grain yield by increasing leaf area, leaf area index, plant height and yield components. Sowing before the onset of the summer rains gave the highest grain yield $(2569 \mathrm{~kg} / \mathrm{ha})$ with an increment of $694 \mathrm{~kg} / \mathrm{ha}$ which is equal to $37 \%$ compared to sowing with the onset of the first summer rains $(1875 \mathrm{~kg} / \mathrm{ha})$.

Among methods of sowing, transplanting $(2277 \mathrm{~kg} /$ ha) being statistically at par with direct sowing with hydro seed priming (1914 kg/ha) produced significantly higher grain yield. However, direct sowing with hydro seed priming was superior in in producing higher leaf area and leaf area index and transplanting was superior in increasing plant height, panicle weight and thousand grain weight.

Direct sowing with hydro seed priming was more profitable than direct sowing without hydro seed priming and transplanting. Among the methods of sowing, since transplanting method require more labour for transplanting and difficult to apply in large hectares of land, direct sowing with the onset of first rain after hydro seed priming is more practicable and economical.

\section{Acknowledgement}

The preparation and completion of this work is supported by the National Higher Board Education of Eritrea.

\section{References}

[1] MoA. (2016), Annual report of sorghum production from 2013 to 2015. Ministry of Agriculture, Asmara,
Eritrea.

[2] MoA. (2015), Sorghum and pearl millet: Hamelmalo Sub Zoba- unpublished report,Ministry of Agriculture, Zoba Anseba. Hamelmalo, Eritrea.

[3] Towned, J. Mtakwa, P. W. Mullins, C. E. and Simmonds, L. P. (1996), Soil Physical factors limiting establishment of sorghum and cowpea in two contrasting soil types in the semi-arid tropics. Soil Tillage Research 40: 89-106.

[4] Harris, D. Joshi, A. Khan, P.A. Gothakar, P. and Sodhi, P. S. (1999), On-farm seed priming in semi-arid agriculture: Development and evaluation in corn, rice and chickpea in India using participatory methods. Experimental Agriculture 35:15-29.

[5] Harris, D. (2006), Development and testing of "onfarm" seed priming. Advances in Agronomy 90: 129178.

[6] Clark, L. E. (1997), Grain sorghum production in the Texas rolling plains. Texas A \&amp; M University Agricultural Research and Extension Center at Chillicothe-Vernon. Technical Report 97-1. In B. Diawara. 2012. Effect of sowing date on growth, development and yield of grain sorghum hybrids. A thesis submitted in partial fulfilment of the requirements for the Masters of Science Degree. College of Agriculture. Department of Agronomy. Kansas State University Manhattan, Kansas. Available at: http://krex.kstate. edu/dspace/bitstream [Accessed on August 12, 2015].

[7] Tabatabaei, S. A. (2013), Effect of salicylic acid and ascorbic acid on Germination indexes and enzyme activity of sorghum seeds under drought stress. Available at:www.jspb.ru/issues/2013/N4/JSPB_2013. [Accessed on December 28, 2015].

[8] Chivasa, W. Harris, D. and Nyamudeza, P. (2001), Determination of optimum on-farm seed priming time for maize (Zea mays L) and sorghum (Sorghum bicolor (L.) Moench) for use to improve stand establishment in semi-arid agriculture. Tanzanian Journal of Agricultural Sciences 3 (2): 103-112.

[9] Bahar, H.A. Adam, K.I. and Mohammed Ali, S.A. (2015b), Performance of Some Sorghum (Sorghum bicolor L. Moench) Varieties under Rain-Fed Condition at Zalingei Area, Sudan (Growth, Yield, Pests and Diseases). Available at:http://www.aiscience.org/ journal/abs [Accessed on March 12, 2016].

[10] Bunck, J. H. (1977), Effect of sowing date on leaf number and total leaf area of hybrid grain sorghum. In B. Diawara. 2012. Effect of sowing dates on growth, development andyield of grain sorghum hybrids. A thesis submitted in partial fulfilment of the requirements for the Degree Master of Science. College of Agriculture. Department of Agronomy. 
Kansas State University Manhattan, Kansas. 2012. Available at: http://krex.kstate.edu/dspace/bitstream/ handle/2097/1 [Accessed on July 24, 2015].

[11] Karhale, M. B. Jaybhaye, P. R. Asewar, B.V. Shinde, P.B. (2014), Effect of different sowing dates on Growth and Yield of Kharif Sorghum Hybrids. Available at:www.iosrjournals.org. [Accessed on November 10, 2015].

[12] Agbaje, G. O. and Olofintoye, J. A. (2002), Effect of Transplanting on yield and growth of grain sorghum (Sorghum bicolor (L.)Moench). Technical notes. Available at:https://www.unilorin.edu.n. [Accessed on August 22, 2015].

[13] Hassanpouraghdam, M. B. Pardaz, J. E and Akhtar, N. F. (2009), The effect of osmo-priming on germination and seedling growth of Brassica napus L. under salinity conditions. Journal of Food, Agriculture \&amp; Environment 7: 620-622.

[14] Khan, S., Anwar, K. Ullah, H. Gul, H. and Rehman, A. U. (2014), Phenology and tissue potassium concentration of sorghum as affected by various sources and levels of osmo priming. Science Park Research Journal 1 (25): 2321-8045.

[15] Conley, S.P. and Wiebold, W. J. (2003), Grain sorghum response to sowing date.Online. Crop Management doi: 10.1094/CM-2003-0204-01-RS. Available at:http://www.researchgate.net/publication/22871432 [Accessed on January 28, 2016].

[16] Murungu, F. S. Chiduza, C. Nyamugafata, P. Clark, L.J. and Whalley, W.R. (2004),Effects of "on-farm seed priming" on consecutive daily sowing occasions on the emergence and growth of maize in semi-arid Zimbabwe. Available at:www.sciencedirect.com/science/article/ [Accessed on July 22, 2015].

[17] Young, E. M. and Mottran, A. (2003), Transplanting sorghum and millet as a means of increasing food security in upper East Region of Ghana. A project summary - Ghana, February 2003. Available at:www. bangor.ac.uk/tran [Accessed on August 16, 2015].

[18] Abdalla, E. A. Osman, A. K. Maki, M. A. Nur, F. M. Ali, S. B. and Aune, J. B. (2015), The response of sorghum, groundnut, sesame, and cowpea to seed priming and fertilizer micro-dosing in South Kordofan State, Sudan. Available at: www.mdpi.com20734395/5/4/476 [Accessed on August 22, 2015].

[19] Mahmood, A. (2012), Performance of Sorghum (Sorghum bicolor L. Moench) as an Energy Crop for Biogas Production. A thesis submitted for the requirement of Doctoral Degree in Agriculture from Faculty of Agricultural and Nutritional Sciences, Home Economics and Environmental Management Justus Liebig University Giessen,Germany. Available at: www.geb.
uni-giessen.de/M. [Accessed on January 11,2016].

[20] Reddy, S.R. (2008), Principles of crop production. 3 rd edn. Kalayani publishers, New Delhi, India.

[21] Diawara, B. (2012), Effect of sowing dates on growth, development and yield of grain sorghum hybrids. A thesis submitted in partial fulfilment of the requirements for the Degree Master of Science. College of Agriculture. Department of Agronomy. Kansas State University Manhattan, Kansas. 2012. Available at: http://krex.kstate.edu/dspace/[Accessed on June 14, 2015].

[22] Rao, S. S. Patil, J. V. Prasad, P. V. V. Reddy, D. C. S. Mishra, J. S. Umakanth, A. V.Reddy, B. V.S. and Kumar, A. A. (2013), Sweet Sorghum Sowing Effects on StalkYield and Sugar Quality in Semi-Arid Tropical Environment. Agronomy Journal 105(5):1458-1465 Available at: www.icrisat.org [Accessed on March 23, 2016].

[23] Assefa, D. Maru, B. Diress, T. and Mitiku, H. (2007), Transplanting Sorghum as a Means of Ensuring Food Security in Low Rainfall Sorghum Growing Areas of Northern Ethiopia. DCG Report No. 48 March 2007. Available at:https://www.agris.fao.org/agris-search/ search.do [Accessed on August 12, 2015].

[24] Ramamurthy, V. Gajbhiyek, S. Venugopalan, M. V. and Parhad, V. N. (2005), On-farm evaluation of seed priming technology in sorghum (Sorghum bicolor L.). Available at:www.agriculturaits.czu.cz. [Accessed on December 23, 2015].

[25] Harris, D. Pathan, A. K. Gothkar, P. Joshi A. Chivasa, W. and Nyamudeza, P. (2007), On-farm seed priming using participatory methods to revive and refine a key technology. Agricultural Systems 69:151-164.

[26] Sankarpondian, R. Krishnadas, D. Muppidathi, N. and Chidambaram, S. (1993), Variability studies in grain sorghum for certain physiological characters under water stress condition. Crop Improvement 20:45-50.

[27] Ezeaku, I. E. and Mohammed, S.G. (2005), Character association and path analysis in grain sorghum. Available at:www.ajol.info. [Accessed on April 10, 2016].

[28] Arunah, U.L. Chiezey, U. F. Aliyu, L. and Ahmed, A. (2015), Correlation and Path Analysis between Sorghum Yield to Growth and Yield Characters. Available at:www.iiste.org [Accessed on Aprile 6, 2016].

[29] Sarvari, S. M. and Beheshti, S. A. (2012), Relationship between Grain Yield and Plant Characteristics in Grain Sorghum Genotypes under Drought Stress Conditions. Iranian Journal of Crop Sciences 14(2):183-201.Available at:www.en.journals.sid.ir/ViewPaper.aspx?ID=31. [Accessed on April 20, 2016]. 